\title{
Evaluation of the Role of Glutathione in the Lead-Induced Toxicity in Saccharomyces cerevisiae
}

\author{
Rita R. Perez • Cátia A. Sousa • Thomas Vankeersbilck • \\ Manuela D. Machado • Eduardo V. Soares
}

Received: 17 December 2012/Accepted: 5 March 2013/Published online: 17 April 2013

(c) Springer Science+Business Media New York 2013

\begin{abstract}
The effect of intracellular reduced glutathione (GSH) in the lead stress response of Saccharomyces cerevisiae was investigated. Yeast cells exposed to $\mathrm{Pb}$, for $3 \mathrm{~h}$, lost the cell proliferation capacity (viability) and decreased intracellular GSH level. The Pb-induced loss of cell viability was compared among yeast cells deficient in GSHI $(\Delta g s h 1)$ or $G S H 2(\Delta g s h 2)$ genes and wild-type (WT) cells. When exposed to $\mathrm{Pb}, \Delta g s h 1$ and $\Delta g s h 2$ cells did not display an increased loss of viability, compared with WT cells. However, the depletion of cellular thiols, including GSH, by treatment of WT cells with iodoacetamide (an alkylating agent, which binds covalently to thiol group), increased the loss of viability in Pb-treated cells. In contrast, GSH enrichment, due to the incubation of WT cells with amino acids mixture constituting GSH (L-glutamic acid, L-cysteine and glycine), reduced the $\mathrm{Pb}$-induced loss of proliferation capacity. The obtained results suggest that intracellular GSH is involved in the defence against the $\mathrm{Pb}$ induced toxicity; however, at physiological concentration,
\end{abstract}

R. R. Perez - C. A. Sousa - T. Vankeersbilck .

M. D. Machado · E. V. Soares ( $\square)$

Bioengineering Laboratory-CIETI, Chemical Engineering

Department, ISEP-School of Engineering of Polytechnic

Institute of Porto, Rua Dr António Bernardino de Almeida,

431, 4200-072 Porto, Portugal

e-mail: evs@isep.ipp.pt

T. Vankeersbilck

Department Industrial Engineering, KaHo St.-Lieven,

Gebroeders Desmetstraat 1, 9000 Ghent, Belgium

M. D. Machado - E. V. Soares

IBB-Institute for Biotechnology and Bioengineering, Centre for

Biological Engineering, Universidade do Minho, Campus de

Gualtar, 4710-057 Braga, Portugal
GSH seems not to be sufficient to prevent the $\mathrm{Pb}$-induced loss of cell viability.

\section{Introduction}

Although lead occurs naturally, its presence in the environment comes, mainly, from human activities, like mining or smelting of ore, manufacture of lead-containing products (such as car batteries), combustion of coal and oil, and waste incineration. Lead is a non-essential metal for biological functions and is classified by the International Agency for Research on Cancer as probable human carcinogen [1].

The yeast Saccharomyces cerevisiae is a suitable eukaryotic model organism for studying $\mathrm{Pb}$ toxic effects, since its cellular structure and functional organization share many similarities with animal and plant cells. This yeast can be easily manipulated, presents a short generation time and has the genome completely sequenced. In addition, valuable tools are available such as the yeast deletion strain collection for understanding gene functions [22].

In $S$. cerevisiae, $\mathrm{Pb}$ inhibits metabolic activity [23] and cell growth, impairs ammonium assimilation and reduces DNA/RNA ratio [4]. In addition, it was shown that $\mathrm{Pb}$ induces the intracellular accumulation of reactive oxygen species (ROS), which can be the trigger of programmed cell death by apoptosis [3].

Yeast cells have different protection mechanisms for controlling the levels of ROS, which can be, basically, divided in enzymatic (superoxide dismutases, catalases and peroxidases) and non-enzymatic defences (as glutathione and trehalose) [10, 12].

The tripeptide glutathione (L- $\gamma$-glutamyl-L-cysteinylglycine) is the main intracellular low molecular mass thiol. 
Glutathione is present in cells, principally, as reduced form-GSH [15, 17]. GSH is biosynthesized in two sequential steps: (i) in the first step, the dipeptide $\mathrm{L}-\gamma$ glutamylcysteine is synthesized, from the L-glutamic acid and L-cysteine, catalyzed by the enzyme L- $\gamma$-glutamylcysteine synthetase (GSHI gene product); and (ii) in the second step, glycine is added to the C-terminal of $\gamma$-glutamylcysteine, by the action of glutathione synthetase (GSH2 gene product), to synthesize GSH [7, 17].

GSH play different functions in yeast cells such as: (i) radical scavenger, by reacting directly with radical hydroxyl to reduce it to $\mathrm{H}_{2} \mathrm{O}$ [7]; (ii) electron donor to glutathione peroxidases (GPX) and glutaredoxins, which catalyzes the reduction of $\mathrm{H}_{2} \mathrm{O}_{2}$ and organic peroxides to $\mathrm{H}_{2} \mathrm{O}$ and the corresponding alcohols, respectively [10]. In these processes, the GSH is oxidized to glutathione disulphide (GSSG). Glutathione can be reduced back by the action of glutathione reductase with the consumption of $\mathrm{NADPH}$, which is essential to the maintenance of a high reduced-oxidized ratio inside the cell [7, 12].

Several works have shown the role of GSH in the protection of the cells against the damage provoked by oxidative stress [11], xenobiotics, carcinogens, radiation [15] and heavy metals [Cd, As(III), Sb(III), Se and $\mathrm{Hg}][6,18$, 25]. GSH seems to be a key molecule in the defence against oxidative stress and metal toxicity. The involvement of GSH in metal detoxification can be carried out in several ways: (i) binding to metals and subsequent vacuolar sequestration; (ii) impairing metal-induced oxidative stress, by the mechanisms presented above; and (iii) binding to sulphhydryl groups on proteins (protein glutathionylation), protecting them from irreversible metal binding and/or oxidative damage [25]. However, the role of GSH in $\mathrm{Pb}$ stress responses, in the yeast $S$. cerevisiae, is unknown.

The present work aims to examine the role of intracellular GSH in Pb-induced toxicity in S. cerevisiae. For this purpose, the loss of viability induced by $\mathrm{Pb}$ was evaluated in wild-type (WT) and GSH-deficient mutant strains. In addition, intracellular GSH content of WT cells was modulated by incubation with iodoacetamide (to deplete cellular thiols, including GSH) or with the mixture of amino acids that make up GSH (GSH-enriched cells); in both cases, the influence of the depletion or GSH enrichment on the modification of the susceptibility of yeast cells to $\mathrm{Pb}$ was studied.

\section{Material and Methods}

Strains, Media and Culture Conditions

Saccharomyces cerevisiae WT yeast strain BY4741 (MATa his $3 \Delta 1$ leu $2 \Delta 0$ met15 $\Delta 0$ ura3 $\Delta 0$ ) and the isogenic mutants $\Delta g s h 1$ and $\Delta g h s 2$ were obtained from EUROSCARF collection and used in this work.

The strains were routinely maintained at $4{ }^{\circ} \mathrm{C}$ on YPD agar slants [10 g/l yeast extract (Difco-BD), $20 \mathrm{~g} / \mathrm{l}$ peptone (DifcoBD), $20 \mathrm{~g} / 1$ glucose (Merck) and $20 \mathrm{~g} / 1$ agar (Merck)]. Mutants were maintained under a selective pressure in YPD agar with $0.02 \%(\mathrm{w} / \mathrm{v})$ geneticin (Sigma-Aldrich).

Pre-cultures were prepared in $10 \mathrm{ml}$ of YPD broth in $100 \mathrm{ml}$ Erlenmeyer flasks. Cells were incubated at $25{ }^{\circ} \mathrm{C}$ on an orbital shaker, at $150 \mathrm{rpm}$, for $8-10 \mathrm{~h}$. Cultures in exponential growth phase were obtained by inoculating $100 \mathrm{ml}$ of YPD broth, in $250 \mathrm{ml}$ Erlenmeyer flasks, with pre-cultures and grown overnight $\left(\mathrm{OD}_{600} \sim 1.0\right)$ under the same conditions as the pre-culture.

Treatment of Yeast Cells with $\mathrm{Pb}$

After growth, cells were harvested by centrifugation $(2,000 \times g, 5 \mathrm{~min})$, washed twice with deionized water and resuspended in 2-(N-morpholino) ethanesulphonic acid (MES) $\mathrm{pH}$ buffer (Sigma-Aldrich, St. Louis, MO, USA) $10 \mathrm{mmol} / \mathrm{l}$, at $\mathrm{pH} 6.0$, with $2 \%(\mathrm{w} / \mathrm{v})$ glucose, to $\sim 1 \times 10^{7}$ cells $/ \mathrm{ml}$. MES is a suitable $\mathrm{pH}$ buffer for heavy metal toxicity studies because it does not complex lead [20] and yeast cells maintain viability when incubated in this buffer for $48 \mathrm{~h}$ [19].

Cell suspensions $\left(40 \mathrm{ml}\right.$ ) containing $1 \times 10^{7}$ cells $/ \mathrm{ml}$, in $10 \mathrm{mmol} / \mathrm{l} \mathrm{MES} \mathrm{buffer}$ (pH 6.0), with $2 \%$ (w/v) glucose and the appropriate volume of lead solution $\left[\mathrm{Pb}\left(\mathrm{NO}_{3}\right)_{2}\right]$, from a stock standard solution of 2,000 mg/l (Merck) were shaken in 100-ml Erlenmeyer flasks at $150 \mathrm{rpm}$, at $25^{\circ} \mathrm{C}$. Cells were treated using a $\mathrm{Pb}$ concentration range of $0-1,000 \mu \mathrm{mol} / \mathrm{l}$ in order to induce a toxic effect (evaluated by the loss of cell proliferation capacity) in wild-type strain of 0-90\%.

\section{Glutathione Enrichment and Depletion Assays}

Enrichment of intracellular glutathione content was carried out as previously described [11]. Briefly, WT yeast cells, $1 \times 10^{7} \mathrm{cells} / \mathrm{ml}$, in exponential growth phase, were incubated in the dark, with shaking $(150 \mathrm{rpm})$, at $25^{\circ} \mathrm{C}$, for $1 \mathrm{~h}$, with a mixture containing $0.5 \mathrm{~mol} / \mathrm{l}$ glucose, $0.01 \mathrm{~mol} /$ $1 \mathrm{MgCl}_{2}, 0.02 \mathrm{~mol} / \mathrm{l} \mathrm{L}$-glutamic acid, $0.02 \mathrm{~mol} / \mathrm{l}$ L-cysteine, $0.02 \mathrm{~mol} / \mathrm{l}$ glycine and $0.1 \mathrm{~mol} / \mathrm{l}$ potassium phosphate buffer ( $\mathrm{pH}$ 7.4). In the pre-treatment with cysteine, cells were incubated with the mixture described above without L-glutamic acid and glycine.

For depletion of glutathione, $1 \times 10^{7}$ cells $/ \mathrm{ml}$, in exponential growth phase, were incubated in the dark, with shaking $(150 \mathrm{rpm})$, at $25^{\circ} \mathrm{C}$, for $1 \mathrm{~h}$, with $1 \mathrm{mmol} / 1$ iodoacetamide (Sigma-Aldrich).

After the treatment, cells were washed twice with deionized water, suspended in $10 \mathrm{mmol} / \mathrm{l} \mathrm{MES}$ buffer, at 
$\mathrm{pH} 6.0$, with $2 \%(\mathrm{w} / \mathrm{v})$ glucose and exposed to $\mathrm{Pb}$ as described above.

\section{Viability Measurement}

Viability was determined by plating the cells on YPD agar. Thus, samples $(1.0 \mathrm{ml}$; two-three replicates) were taken at defined intervals of time, serially diluted with sterile deionized water and plated (two replicates of $200 \mu \mathrm{l}$ of the convenient dilutions). The colonies were counted after $3-4$ days of incubation at $25^{\circ} \mathrm{C}$. The $\%$ of survivors was calculated using the number of colony-forming units (c.f.u)/ml at zero time as reference $(100 \%)$.

Evaluation of Intracellular Reduced Glutathione Content

Intracellular GSH was monitored with monochlorobimane (mBCl, Sigma-Aldrich) as previously described [21] with minor modifications. After exposition to $1,000 \mu \mathrm{mol} / \mathrm{l} \mathrm{Pb}$, for $3 \mathrm{~h}$, cells were washed once with deionized water, suspended at $1 \times 10^{7} \mathrm{cells} / \mathrm{ml}$ in $0.1 \mathrm{~mol} / 1$ phosphate buffered saline solution (PBS buffer), at $\mathrm{pH}$ 7.0, and incubated with $\mathrm{mBCl}$ (in a final concentration of $50 \mu \mathrm{mol} /$ 1), for $2 \mathrm{~h}$, at $25^{\circ} \mathrm{C}$, in the dark. Stock solutions of $50 \mathrm{mmol} / \mathrm{l} \mathrm{mBCl}$ were prepared in dimethyl sulphoxide (Sigma-Aldrich) and stored at $-20{ }^{\circ} \mathrm{C}$; working solutions of $1 \mathrm{mmol} / \mathrm{l}$ were prepared in PBS buffer, $\mathrm{pH} 7.0$, just before use. Fluorescence intensity (as relative fluorescent units-RFU) was measured using a microplate reader at fluorescence excitation of $355 / 40 \mathrm{~nm}$ and an emission of 460/25 nm. Fluorescence was normalized (considering cell concentration) and corrected by subtracting cell, buffer and dye autofluorescence.

For epifluorescence microscopy analysis, $1 \times 10^{7}$ cells/ $\mathrm{ml}$ were suspended in $0.1 \mathrm{~mol} / \mathrm{l} \mathrm{PBS}$ buffer $(\mathrm{pH} 7.0)$ and incubated with $\mathrm{mBCl}$ (in a final concentration of $100 \mu \mathrm{mol} /$ 1), for $60 \mathrm{~min}$, at $25^{\circ} \mathrm{C}$, in the dark; cells were examined using a Leica DLMB epifluorescence microscope equipped with a HBO-100 mercury lamp and the filter set A [excitation filter (band pass filter, BP) BP 340-380, dichromatic mirror 400 and suppression filter (long pass filter, LP) LP 425], from Leica. The images were acquired with a Leica DC $300 \mathrm{~F}$ camera using $\mathrm{N}$ plan objectives and processed using Leica IM 50-Image manager software.

Reproducibility of the Results

All experiments were repeated, independently, four times. Fluorescence data were expressed as the mean \pm standard deviation (SD), presented with $95 \%$ confidence value, of quintuplicate measurements of a typical experiment. The data reported for viability were the mean $\pm \mathrm{SD}$, presented with $95 \%$ confidence value of four independent experiments.

\section{Results and Discussion}

$\mathrm{Pb}$-induced Loss of Viability in Wild-Type and Glutathione-Deficient Mutants

The exposition of $S$. cerevisiae cells to $\mathrm{Pb}$ resulted in a marked intracellular ROS accumulation [3]. GSH is the main redox buffer of the cells being a key factor against the oxidative stress and metals toxicity [25]. In this context, the effect of reduced GSH on the protection against $\mathrm{Pb}$ induced toxicity was evaluated using the WT strain and the knockout mutants devoid in the genes GSH1 or GSH2, responsible for the enzymes $\mathrm{L}-\gamma$-glutamylcysteine synthetase and $\gamma$-glutamylcysteine, respectively.

Saccharomyces cerevisiae WT cells, in exponential phase of growth, when exposed to different $\mathrm{Pb}$ concentrations, for $3 \mathrm{~h}$, lose the viability, assessed by c.f.u. counting on YPD plates, in a dose-dependent manner. The survival of WT cells exposed to 500 or $1,000 \mu \mathrm{mol} / \mathrm{l} \mathrm{Pb}$, for $3 \mathrm{~h}$, was 43 or $8 \%$ of cells, respectively (Fig. 1); i.e. these $\mathrm{Pb}$ concentrations induced a loss of cell proliferation capacity of 57 and $92 \%$, respectively.

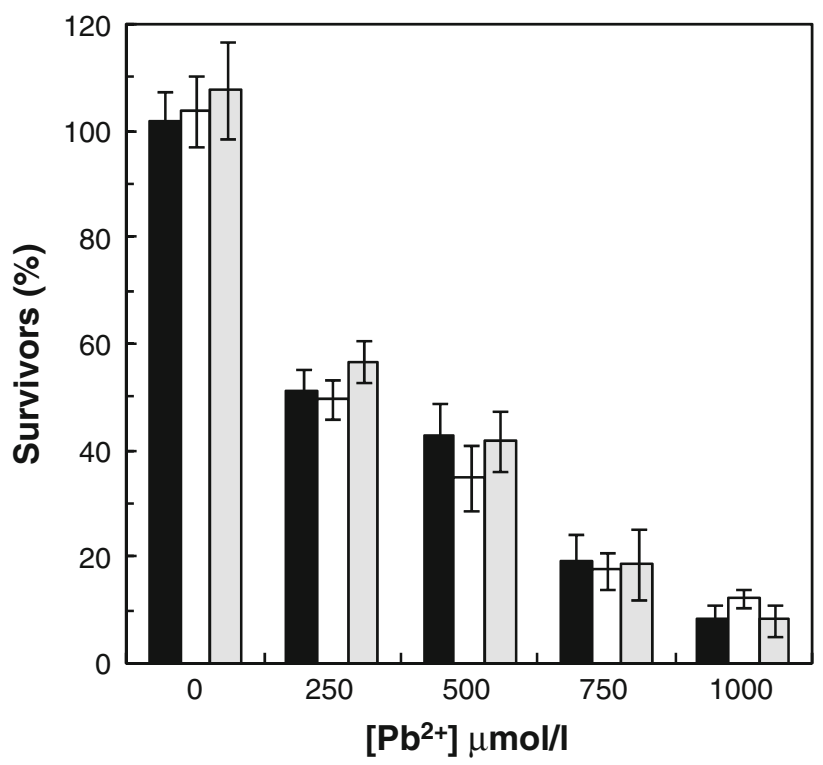

Fig. 1 Comparison of the susceptibility to $\mathrm{Pb}$ of wild-type and GSHdeficient mutant strains of $S$. cerevisiae. Cells in exponential phase of growth of the wild-type strain BY4741 (dark bar) or the isogenic GSH-deficient mutant strains $\Delta g s h 1$ (white bar) and $\Delta g s h 2$ (grey bar) were treated with different $\mathrm{Pb}$ concentrations for $3 \mathrm{~h}$. Viability was estimated by c.f.u. counts. Each bar represents the mean of four independent experiments. Standard deviations are presented with $95 \%$ confidence limits (vertical error bars) 


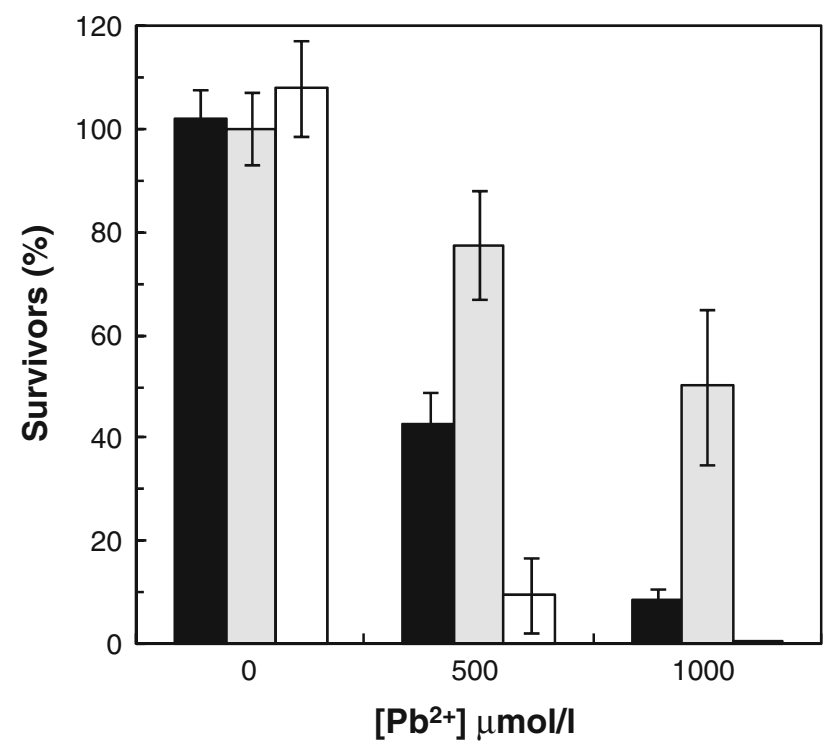

Fig. 2 Impact of iodoacetamide or amino acids mixture constituting $\mathrm{GSH}$ on the viability of Pb-exposed cells of $S$. cerevisiae. Cells of the wild-type strain BY4741, in exponential phase of growth, were incubated with $1 \mathrm{mmol} / \mathrm{l}$ iodoacetamide (white bar) or with a mixture containing $0.5 \mathrm{~mol} / \mathrm{l}$ glucose and $0.02 \mathrm{~mol} / \mathrm{l} \mathrm{L}$-glutamate, L-cysteine and glycine (grey bar), for $1 \mathrm{~h}$, at $25^{\circ} \mathrm{C}$, before being exposed to $\mathrm{Pb}$, for $3 \mathrm{~h}$. As control, cells of the wild-type strain BY4741 in exponential phase of growth (non-treated cells-black bar) were exposed to $\mathrm{Pb}$ for $3 \mathrm{~h}$. Viability was estimated by c.f.u. counts. Each bar represents the mean of four independent experiments. Standard deviations are presented with $95 \%$ confidence limits (vertical error bars)

Yeast cells lacking GSHl gene $(\Delta g s h l)$ are completely avoided of GSH; cells lacking $G S H 2$ gene $(\Delta g s h 2)$ are able to synthesize L-glutamylcysteine, from L-glutamic acid and L-cysteine, but not GSH. The exposition of $\Delta g s h 1$ or $\Delta g s h 2$ mutant strains, to increasing $\mathrm{Pb}$ concentrations, originated a marked loss of cell proliferation. Nevertheless, $\Delta g s h 1$ and $\Delta g s h 2$ strains did not display an increased loss of viability compared to WT strain (Fig. 1).

\section{Change in the Thiol Compounds Content Modify the Sensitivity to $\mathrm{Pb}$}

In order to test if the GSH was not involved as defence mechanism or was not present in enough amount to protect yeast cells against $\mathrm{Pb}$-induced toxicity, cells from WT strain, in exponential phase of growth, were treated, for $1 \mathrm{~h}$, with $1 \mathrm{mmol} / \mathrm{l}$ iodoacetamide (thiol-depleted cells) or with an amino acids mixture constituting GSH (GSHenriched cells), washed and subsequently exposed to $\mathrm{Pb}$.

Chemical induction of GSH depletion can be carried out, basically, through two mechanisms: (i) reaction with $\mathrm{GSH}$, i.e. GSH is depleted due to the reaction with chemicals like diethylmaleate or iodoacetamide; and (ii) by inhibition of GSH biosynthesis with an enzyme inhibitor, a
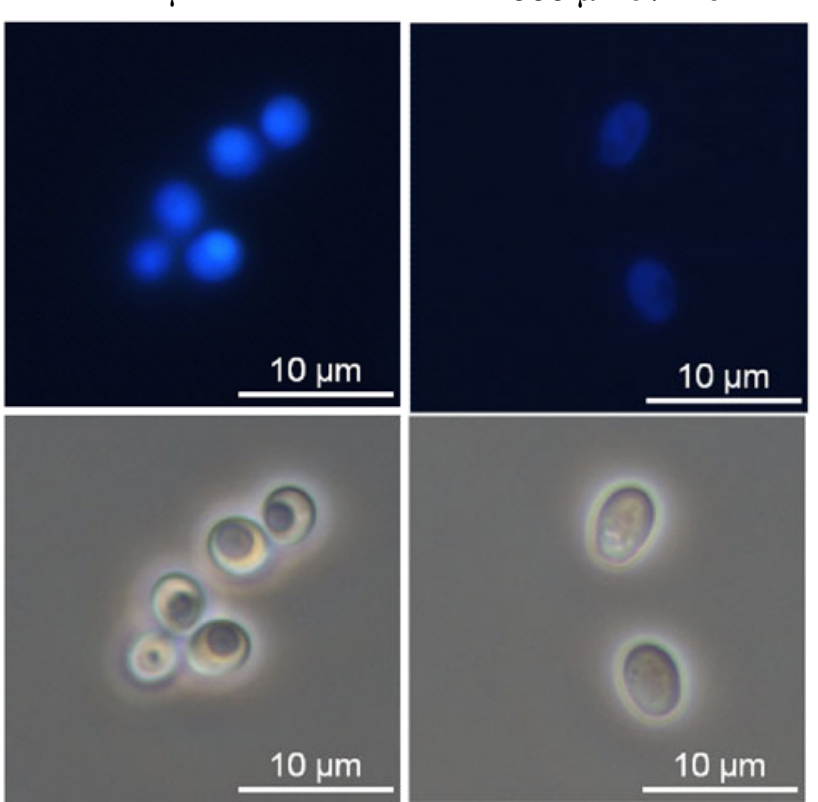

b

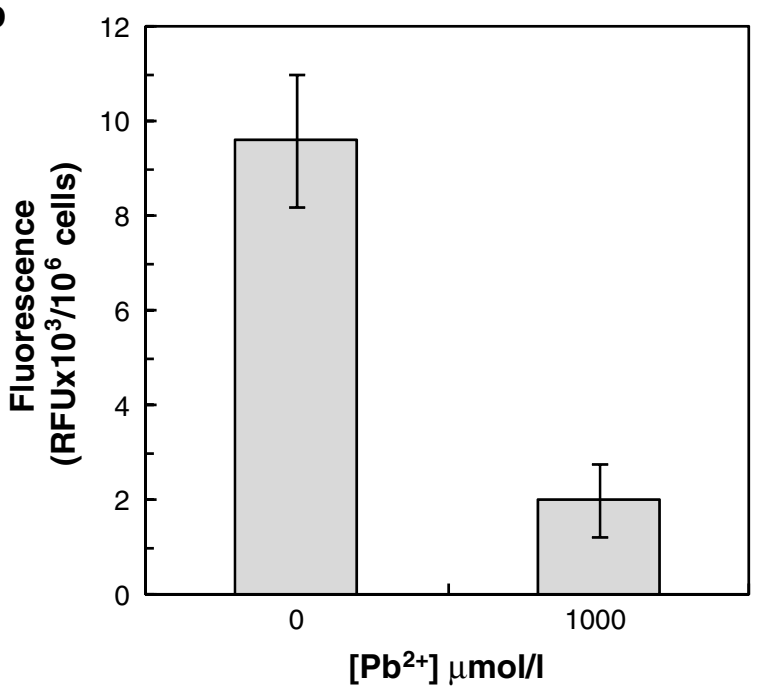

Fig. $3 \mathrm{~Pb}$ exposition induced the decrease of intracellular glutathione content in S. cerevisiae. Cells in exponential phase of growth were incubated for $3 \mathrm{~h}$ in the absence or presence of $1,000 \mu \mathrm{mol} / \mathrm{l} \mathrm{Pb}$; subsequently, cells were washed and incubated with monochlorobimane, for $1 \mathrm{~h}$. Untreated cells exhibited fluorescence (due to the formation of bimane-glutathione conjugates), which was absent in cells exposed to $\mathrm{Pb}(\mathbf{a})$. Quantification of fluorescence $(\mathbf{b})$. This is a typical example of an experiment performed four times; each bar represents the mean of five fluorescent readings. Standard deviations are presented with $95 \%$ confidence limits (vertical error bars)

such as L-buthionine sulphoximine $[13,15]$. With the aim to test the effect of the absence of GSH, on Pb toxicity, by a different way (GSH biosynthesis inhibition was tested with $\Delta g s h$ mutant strains), yeast cells were GSH depleted by treatment with iodoacetamide; this compound was selected due to its efficiency in GSH depletion, in a short 
time [16]. The treatment of yeast cells with iodoacetamide and subsequent staining with $\mathrm{mBCl}$ allowed to verify a severe reduction of intracellular thiol content, including GSH, as no fluorescence was observed in iodoacetamidetreated cells. This observation is in agreement with the results presented in the literature which described that the treatment with iodoacetamide originates a reduction of the GSH to $<5 \%$ of normal levels [16]. On the contrary to GSH-deficient mutants, WT cells pre-treated with iodoacetamide displayed an enhanced sensitivity to $\mathrm{Pb}$ compared to non-treated cells. The survival of thiol-depleted cells to the exposition to 500 or $1,000 \mu \mathrm{mol} / \mathrm{l} \mathrm{Pb}$, for $3 \mathrm{~h}$, was $10 \%$ or $<1 \%$, respectively (Fig. 2). Iodoacetamide is an alkylating agent, which binds covalently to thiol groups [8]. Thus, in addition to GSH depletion, iodoacetamide can also irreversibly inhibit other thiol compounds and enzymes associated with the defence against the oxidative stress; these facts can explain the hypersensitivity of iodoacetamide-treated cells to $\mathrm{Pb}$.

The incubation of WT cells with glucose and L-glutamic acid, L-cysteine and glycine lead to an increase of intracellular levels of GSH [11]. In the presence of 500 or $1,000 \mu \mathrm{mol} / \mathrm{l} \mathrm{Pb}$, for $3 \mathrm{~h}$, the $\mathrm{GSH}$-enriched cells presented a higher viability, comparatively to non-treated cells (Fig. 2); under these conditions, a survival of 78 and $50 \%$, respectively, was observed. The pre-treatment of WT cells with glucose and L-cysteine did not protect the cells against the $\mathrm{Pb}$-induced loss of viability, since a similar $\%$ of survival to non-treated WT cells was observed. Together, these data suggest the involvement of GSH in the defence against the $\mathrm{Pb}$-induced toxicity, for instance, as co-factor of enzymatic defences against oxidative stress (such as GPX enzymes).

\section{$\mathrm{Pb}$ Reduces Intracellular Glutathione Level}

Redox-inactive metals, as is the case of $\mathrm{Pb}$, can produce ROS by indirect mechanisms such as the displacement of redox-active metals from cellular binding sites, the inhibition of specific enzymes associated with antioxidant defences or by depleting pools of antioxidants, such as GSH $[2,25]$.

The intracellular GSH content in S. cerevisiae cells was evaluated using $\mathrm{mBCl}$, a cell-permeant probe. Once inside the cell, the probe is essentially nonfluorescent until conjugated; $\mathrm{mBCl}$ reacts with reduced glutathione and forms fluorescent bimane-glutathione (B-SG) adducts [9]. Cells, in the absence of $\mathrm{Pb}$, exhibited a typical fluorescence due to the formation of B-SG adducts. On the contrary, in Pb-treated cells $(1,000 \mu \mathrm{mol} / \mathrm{l} \mathrm{Pb}$, for $3 \mathrm{~h})$ only a faint fluorescence was observed (Fig. 3a). As described above, similar images of $\mathrm{Pb}$-treated cells were obtained with iodoacetamide-treated cells. The quantification of the fluorescent signal produced due to the formation of B-SG adducts in cells non-treated or treated with $1,000 \mu \mathrm{mol} / \mathrm{l} \mathrm{Pb}$, for $3 \mathrm{~h}$, showed a marked reduction $(\sim 94 \%)$ of fluorescence in $\mathrm{Pb}$-treated cells (Fig. 3b). These results suggested a reduction of intracellular GSH in Pb-exposed yeast cells, which is in agreement with the data presented in the literature, that describe a GSH decrease in kidney, liver and brain cells of rats exposed to lead [5, 24]. It is known that several metals including $\mathrm{Hg}, \mathrm{Cd}$ and $\mathrm{Pb}$ present high affinity to thiol group [14]. The reduction of GSH observed can be due to the affinity of the thiol group of GSH to $\mathrm{Pb}$. Once in the cytosol, $\mathrm{Pb}$ can be complexed by GSH, decreasing the level of GSH.

\section{Conclusions}

The lack of GSH1 or GSH2 genes did not enhance the susceptibility of the yeast cells to the toxic action of $\mathrm{Pb}$. However, the manipulation of intracellular GSH content modified, markedly, the viability in Pb-exposed cells. In addition, the exposition to $\mathrm{Pb}$ decreased the intracellular GSH level. These results suggest that intracellular GSH is involved in the $\mathrm{Pb}$ detoxification; however, at physiological concentration, GSH seems not enough, per se, to halt the $\mathrm{Pb}$-induced loss of cell viability.

\section{References}

1. ATSDR (2007) Toxicological profile for lead. Agency for Toxic Substances and Disease Registry (ATSDR). US Department of Health and Human Services-Public Health Service

2. Avery SV (2001) Metal toxicity in yeasts and the role of oxidative stress. Adv Appl Microbiol 49:111-142

3. Bussche JV, Soares EV (2011) Lead induces oxidative stress and phenotypic markers of apoptosis in Saccharomyces cerevisiae. Appl Microbiol Biotechnol 90:679-687

4. Chen C, Wang JL (2007) Response of Saccharomyces cerevisiae to lead ion stress. Appl Microbiol Biotechnol 74:683-687

5. Ercal N, Gurer-Orhan H, Aykin-Burns N (2001) Toxic metals and oxidative stress part I: mechanisms involved in metal-induced oxidative damage. Curr Top Med Chem 1:529-539

6. Gharieb MM, Gadd GM (2004) Role of glutathione in detoxification of metal(loid)s by Saccharomyces cerevisiae. Biometals $17: 183-188$

7. Grant CM (2001) Role of the glutathione/glutaredoxin and thioredoxin systems in yeast growth and response to stress conditions. Mol Microbiol 39:533-541

8. Hansen RE, Winther JR (2009) An introduction to methods for analyzing thiols and disulfides: reactions, reagents, and practical considerations. Anal Biochem 394:147-158

9. Haugland RP (2005) The handbook - a guide to fluorescent probes and labeling technologies, 10th edn. Invitrogen Corp, Eugene

10. Herrero E, Ros J, Belli G, Cabiscol E (2008) Redox control and oxidative stress in yeast cells. Biochim Biophys Acta 1780:1217-1235

11. Izawa S, Inoue Y, Kimura A (1995) Oxidative stress response in yeast : effect of glutathione on adaptation to hydrogen peroxide stress in Saccharomyces cerevisiae. FEBS Lett 368:73-76 
12. Jamieson DJ (1998) Oxidative stress responses of the yeast Saccharomyces cerevisiae. Yeast 14:1511-1527

13. Markovic J, Mora NJ, Broseta AM, Gimeno A, de-la-Concepcion N, Vina J, Pallardo FV (2009) The depletion of nuclear glutathione impairs cell proliferation in $3 \mathrm{t} 3$ fibroblasts. PLoS ONE 4:e6413

14. Martell AE, Smith RM (2004) NIST Standard Reference Database 46 version 8.0. In: (eds) US Department of Commerce, National Institute of Standards and Technology, NIST Critically Selected Stability Constants of Metal Complexes Database

15. Meister A (1988) Glutathione metabolism and its selective modification. J Biol Chem 263:17205-17208

16. Millard PJ, Roth BL, Thi HPT, Yue ST, Haugland RP (1997) Development of the FUN-1 family of fluorescent probes for vacuole labeling and viability testing of yeasts. Appl Environ Microbiol 63:2897-2905

17. Penninckx M (2000) A short review on the role of glutathione in the response of yeasts to nutritional, environmental, and oxidative stresses. Enzyme Microb Technol 26:737-742

18. Prévéral S, Ansoborlo E, Mari S, Vavasseur A, Forestier C (2006) Metal(loid)s and radionuclides cytotoxicity in Saccharomyces cerevisiae. Role of YCF1, glutathione and effect of buthionine sulfoximine. Biochimie 88:1651-1663
19. Soares EV, Duarte A, Soares H (2000) Study of the suitability of 2-(N-morpholino) ethanesulfonic acid $\mathrm{pH}$ buffer for heavy metals accumulation studies using Saccharomyces cerevisiae. Chem Speciat Bioavailable 12:59-65

20. Soares HMVM, Conde PCFL, Almeida AAN, Vasconcelos MTSD (1999) Evaluation of $n$-substituted aminosulfonic acid pH buffers with a morpholinic ring for cadmium and lead speciation studies by electroanalytical techniques. Anal Chim Acta 394:325-335

21. Staleva L, Manga P, Orlow SJ (2002) Pink-eyed dilution protein modulates arsenic sensitivity and intracellular glutathione metabolism. Mol Biol Cell 13:4206-4220

22. Suter B, Auerbach D, Stagljar I (2006) Yeast-based functional genomics and proteomics technologies: the first 15 years and beyond. Biotechniques 40:625-644

23. Van der Heggen M, Martins S, Flores G, Soares EV (2010) Lead toxicity in Saccharomyces cerevisiae. Appl Microbiol Biotechnol 88:1355-1361

24. Wang JC, Yang ZJ, Lin L, Zhao ZQ, Liu ZP, Liu XZ (2012) Protective effect of naringenin against lead-induced oxidative stress in rats. Biol Trace Elem Res 146:354-359

25. Wysocki R, Tamás MJ (2010) How Saccharomyces cerevisiae copes with toxic metals and metalloids. FEMS Microbiol Rev 34:925-951 